\title{
Rocking the boat:
}

\section{Proposing a participatory business model for news}

Lene Pettersen, Arne Krumsvik

The digitization of newspapers has opened up new possibilities for user involvement, yet established practices in the media industry hinder news organisations from fully exploiting the many new opportunities that exist in the age of the Internet and social media. In this conceptual and interdisciplinary article, we explain how news actors' strategic choices for innovation related to citizen collaboration and knowledge creation lead to distinct ideal types for participatory business models for news organisations, which we label the three C's (citizen reporting, citizen journalism, and citizen media). We contribute to the business model innovation literature by pointing to which specific parts of a business model that news actors need to change in order to cut their production costs, as well as contributing to innovation theory by showing that the three C's is a continuum of innovational steps. We develop further the donation strategy for user involvement by discussing citizen collaboration in different parts of the journalistic value chain. We con- clude that news actors need to rock their boats in order to innovate their business models in line with today's media landscape.

\section{Keywords}

business model innovation, business canvas modelling, citizen journalism, co-creation, donation strategy, social innovation, user involvement

\section{INTRODUCTION}

The news media have experienced declining profits and layoffs, and downsizing of newsrooms occurs globally. Despite that some media players have succeeded with their online presence, news actors worldwide are seeking sustainable business models (BM) for the news industry (Krumsvik, 2018). For example, Slate.fr, a French version of the US-magazine, generated about 800 ooo euro in revenue in 2009-10, yet the operating costs were twice that amount (Bruno \&
Klein Nilsen, 2012, p. 42). De-professionalization of journalism is one of the effects, leading to more usercreated content, especially in local media (Nygren, 2008). New content models are tested to attract readers, such as content marketing, where commercial and editorial content become blurred and overlap (Barland \& Olsen, 2015). Another consequence from the current media situation is that content risks being produced with traffic and click- or share-rates as key performance indicators. This might significantly affect the types of content chosen for publication, which are critical to ensure an enlightened democracy. Although the press has tried to create value from online advertising via detailed data about users gathered from cookies on users' devices, it is well known that Google and Facebook have repossessed the advertising market.

Despite a few new efforts, online newspapers are still creating economic revenue via traditional prin- 
ciples (content production by professional journalists and pay per copy or subscriptions). Most news organisations follow established practices: production and distribution of content still remain under the control of news actors, typically because traditional journalists fear the weakening of professional norms or the news media's credibility (Krumsvik, 2013, 2018; Moore \& Hatcher, 2019).

A key role of the news media is to facilitate public deliberation, and the political privileges of the media (i.e., direct and indirect subsidies, licences, exceptions to regulations) are also rooted in this role due to the link to political participation. The philosophical debate on the relationship between journalists and citizens dates back to the 1920s' debate between John Dewey and Walter Lippmann, where the former advocated for citizen involvement, while the latter argued for professional detachment. The digitization of newspapers has opened up new possibilities for user involvement and energized the civic journalism movement inspired by Dewey. Civic journalism advocates did stress the importance of using technology to strengthen the relation between users and professional journalists and to increase democratic participation (Bruns, 2005, 2008; Gillmor, 2004; Haas, 2007; Rosen, 1999, 2000). From an economical point of view, the promise of reduced production and promotion costs makes strategies for social media very interesting for traditional media institutions (Krumsvik, 2013, 2018). However, these technological assets of new media were to a large degree ignored in the development of online journalism by legacy media (Boczkowski, 2004, Domingo, 2008; Matheson, 2004; Schroeder, 2004). Users are mostly empowered to create content related to popular culture and personal/everyday life, and are to a minimal degree involved in news production (Günzel \& Holm, 2013; Jönsson \& Örnebring, 2011) - with the exception of images and video footage from dramatic events (see e.g. Wardle, Dubberley, \& Brown, 2014). The strategic value of user created content has also decreased significantly in the latter years (Krumsvik, 2018). This well documented gap between the ideal promise of digital media and actual practices is a key starting point of this article.

When turning our analytical lens to the theoretical approaches employed in previous research, we find that research on user involvement in news media has mainly been conducted from a democratic perspective (Bruns, 2008; Carpentier, 2011; Gillmor, 2004), where the user is at the centre of most innovations that focus on content production (García-Avilés, Carvajal-Prieto, Arias-Robles, \& Lara-González, 2018), an approach that is also observed in studies of brands (Ind, Iglesias, \& Schultz, 2013), as well as in the sharing economy (Pettersen, 2017). The main attention has been directed towards the users or consumers' perspective, and less from a business perspective. Despite that several studies from different industries investigate the birth of new business models (e.g. music streaming services such as Spotify), few studies have investigated how companies can realign their existing business models to accommodate open innovation practices (Saebi \& Foss, 2015). Hence, we need to look at which specific part in the news actor's business model that needs and could be innovated in order to reduce their production and promotion costs.

Despite no shared understanding of the concept "business model" in the literature, the different schools acknowledge that a business model is facilitating a firm's value creation and value capture (Zott, Amit, \& Massa, 2011). Business models, dynamic capabilities, and strategy are interdependent, yet these relationships are in the literature understood mainly at a theoretical level, and there is a need for "empirical work to flesh out the details" (Teece, 2018, p. 40). Thus, it is the ambition of this article to contribute to filling the abovementioned gaps with a conceptual approach. More specifically, we address the following research question in this article:

Which elements, and to what degree, of news organisations' business model need innovation or change in order to benefit from the user's co-creation of content? 
We argue that user contributions represent an untapped potential that news organisations increasingly ignore in their strategies. Building further on this, we contribute to the literature by showing that innovation is a continuum rather than a dichotomy.

The remaining is organized as follows. We begin with a review of key literature on innovation, co-creation and business model innovation. This is followed by a presentation of user engagement strategies observed in news media varying along an innovation continuum in their value chain. Building further on these models, we present a model of which key components in the news media business models that could to be changed in order to cut production costs. The paper closes by a discussion where we illustrate that in order to exploit the untapped potential of contributions from users or citizens, news organisations need to rock their boats.

INNOVATION, BUSINESS MODEL INNOVATION AND CO-CREATION

Innovation

Innovation is typically interpreted as new objects or products, including ideas or practices that individuals perceive as new (Rogers, 2010). In the literature, innovation is typically described in dichotomous terms; as either small improvements or fundamen- tal changes. The main dichotomy in a Schumpeterian tradition, is that of incremental versus radical innovation. Incremental innovation refers to gradual improvements, where one innovation builds on another. Radical innovation, on the other hand, includes innovations with far-reaching consequences that may change the economy through creative destruction (Schumpeter, 1943). A Schumpeterian view on innovation, emphasises the control of markets, where innovation is mainly about avoiding competition (Whittington, 2001, p. 76). von Hippel (2005), on the other hand, sees innovation from the user's, perspective as a democratized process. In media innovation studies, Francis and Bessant's (2005) framework on business innovation is commonly used. Francis and Bessant (2005) categorize innovation into four P's:

1. product (changes in products/services);

2. process (changes in how products/services are created and distributed);

3. position (changes in how products/services are framed in a specific context);

4. paradigmatic innovation (changes in an organisation's mindset, values and business models).

Media scholars Storsul and Krumsvik (2013) added a fifth dimension to Francis and Bessant's (2005) framework when they categorized media innovation into five types, namely:

5. social (changes that meet social needs and im- prove people's lives).

While Francis and Bessant (2005) four types concern elements related to the organisation, Storsul and Krumsvik's (2013) fifth type concerns aspects detached from the organisation with a specific result listed: reach a certain change. More specifically, Storsul and Krumsvik's (2013) fifth type includes "new practices for resolving societal challenges, which are adopted and utilized by the individuals, social groups and organisations concerned" (Ní Bhroin, 2013, p. 219). Whilst Francis and Bessant (2005) four types primarily focus on value capture (changes in the production chain), Storsul and Krumsvik's (2013) fifth type includes value creation (the perceived benefit to the customer). Finding sustainable ways for media actors to create value is critical to ensure an enlightened and democratic society, and thus concerns all the five innovation types. While Francis and Bessant's (2005) first three types involve aspects that will be discussed in the next section, the fourth type is related to how media actors are reluctant to change their established practices, as was shown in the introduction. In the strategy literature, this aspect is described as a firms dynamic capability in the theory of dynamic capabilities (TDC). TDC stresses that a firm needs to invest in two different goals at the same time; exploitation of the existing and exploration of the new (O'Reilly \& Tushman, 2008; Revang \& Olaisen, 2014). Lasting 
organisational success depends on the firms' ability to engage in the daily operations that secure viability, yet at the same time the firm needs to engage in renewal processes that secure survival in the future (Levinthal \& March, 1993; Revang \& Olaisen, 2014). However, aspects related to the paradigmatic innovation type (changes in an organisation's mindset, values and business models), are found to be key barriers for business model innovation in organisations (Chesbrough, 2010; Saebi, 2016).

Business Model Innovation

There is no shared understanding in the literature of what a business model is except from the understanding of it facilitating value creation and value capture. However, the different perspectives acknowledge that the business model is a unit of analysis that is distinct from the product, firm, industry or network; that it explains how firms do business and that it explains both value creation and value capture (Zott et al., 2011). In Zott et al.'s (2011) review of the business-model literature, they found that the construct "business model" has mainly been used to address three distinct phenomena: (a) e-business and the use of information technology in organisations; (b) strategic issues, such as value creation, competitive advantage and firm performance; and (c) innovation and technology management (p. 1023). Scholars focusing on e-business have mainly been interested in understanding the gestalt of firms engaging in (new) Internet-based ways of doing business and the (new) roles that these firms play in their respective ecosystems (p. 1028). Value creation in the second stream includes the generation of social as well as economic values, a parallel to the five innovation types presented by Storsul and Krumsvik (2013). The third research stream is characterized by two complementary ideas: (1) companies commercialize innovative ideas and technologies through their business models; and (2) business models represent a new subject of innovation, which complements the traditional subjects of process, product and organisational innovation and involves new forms of cooperation and collaboration.

The scholars in the first category state that, although technological innovation is important for firms, there is no guarantee of success because technology per se has no inherent value. Hence, technology enables the designing of a unique business model that fully exploits its potential. Scholars in the second category stress open innovation, co-creating and collaborative entrepreneurship. Value creation mechanisms often go beyond the value that can be created through Schumpeterian innovation, the (re) configuration of the value chain, the formation of strategic networks among firms or the exploitation of firms' specific core competencies (Zott et al., 2011, p. 1029). For example, open innovation looks outside rather than inside the firm for leverage of internal and external idea sources (Chesbrough, 2003). Similarly, collaborative entrepreneurship denotes the creation of value based on jointly generated ideas that emerge from the sharing of information and knowledge (Miles, Miles, \& Snow, 2006). As the theory of dynamic capabilities reminds us, it is important that the organisation is constantly open for new ideas and changes in their business models. However, recent research from a Norwegian context shows that only a small proportion of companies have changed their business model over time (Saebi, 2016). The studies indicate that there are two reasons for the low degree of innovation in business models: (1) managers are not aware of the company's business model; or (2) they hesitate to change the status quo. There are many ways that firms can change or innovate their business models. According to Foss \& Saebi (2015), organisations can do this by: (a) targeting new customer segments; (b) offering new value propositions (new bundle of services and products); (c) capturing value in a novel way (novel pricing mechanisms or new main source of revenue); and/or (d) finding new ways of producing, delivering or distributing existing 
or new products and services to existing or new customer segments.

Despite that several studies looks into the birth of new business models in different industries (e.g. Spotify (music), Netflix (film)), few have, as said, studied in-depth which specific part in the business model that established news players could innovate. Osterwalder \& Pigneur (2010) offer a framework that can assist us with doing this by studying which part of a business model that is up for change in order for news actors to reduce their production costs. Osterwalder \& Pigneur (2010) build their framework on three key value propositions: value creation, value capture, and value delivery. Value creation denotes the perceived benefit to the customer, value capture refers to changes in the production chain, and value delivery involves everything needed for delivering value smoothly and satisfying the customer (e.g. order processing, inventory management, delivery/fulfilment, troubleshooting, customer support). The three value propositions are organized in Osterwalder and Pigneur's (2010) Business Model Canvas (BMC) framework as a business model's back end and front end (Figure 1).

In Osterwalder and Pigneur's (2010) BMC framework, a business model consists of nine interrelated building blocks (see Figure 1). Numbers two to four in the framework constitute value-delivery items, numbers six to eight concerns value-creating elements,

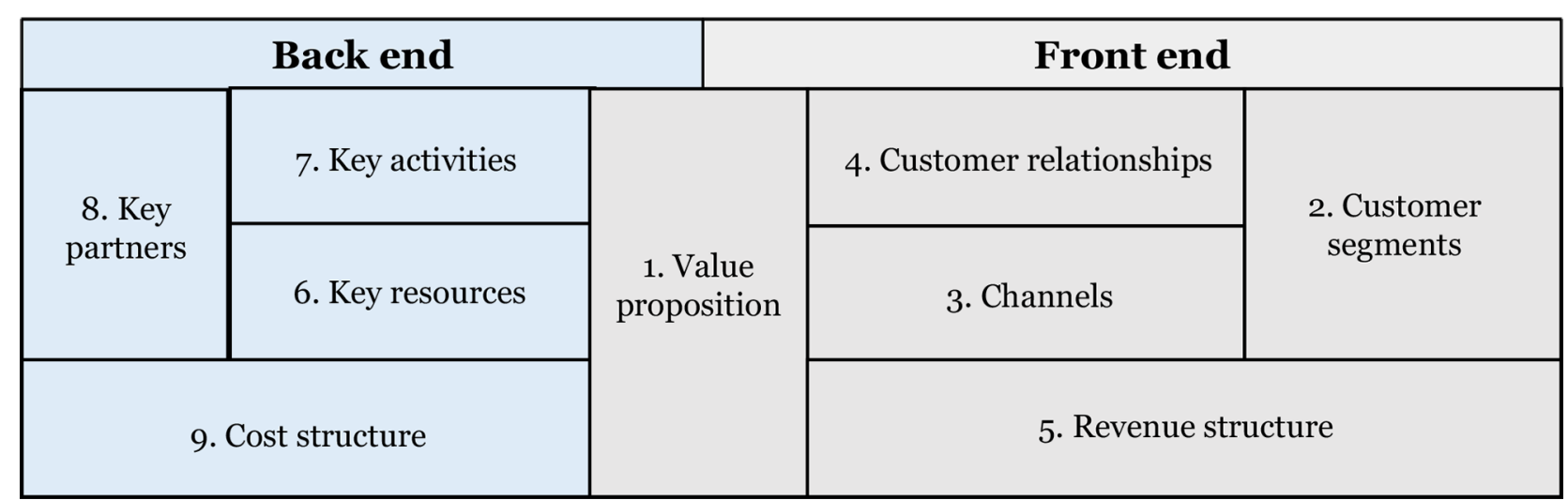

Figure 1: Figure of back end and front end of business models in Osterwalder and Pigneur's (2010) Business Model Canvas framework (CC BY-SA 3.0).

while numbers five and nine are related to valuecapture elements. These nine elements are divided into the front end and back end of the business model framework. The front end (the right side of the figure) emphasizes value, while the back end (the left side of the figure) is predominantly efficiency-driven (Osterwalder \& Pigneur, 2010, p. 49). Put differently, one might say that the back end traditionally concerns the internal factors of a business, while the front end is related to external factors. In this article, we examine how news actors can reduce their production costs yet maintain high quality content, which in turn will assist a diverse and enlighten public sphere. Hence, we explore building blocks located in the business model's front end. Due to the Internet and social media, technology has made it possible to design unique business models, including those where organisations can benefit from resources they do not own (e.g. Airbnb) (Pettersen, 2017; Tapscott, 2001). Furthermore, co-creation and participatory journalism are resources that the news industry can benefit from and consider when they innovate their business models by moving costs related to production of content from the back end to the front end - due to changes in the production chain. 
Co-creation

From a Schumpeterian perspective of innovation, press actors compete on economic terms - an approach often used in studies of media innovations and economics. A von Hippelian perspective on innovation, on the other hand, stresses collaboration in digital online spaces, and in new organising principles, which will allow us to better balance value capture (changes in the production chain) and value creation (the perceived benefit to the customer). Co-creation is the active, creative and social process based on collaboration between organisations and participants that generates benefits for all and creates value for stakeholders (Ind et al., 2013, p. 9). Co-creation can enable organisations to innovate together with customers and other stakeholders, while generating such potential benefits as cost efficiencies, speed to market, and competitive advantage (Iglesias, Ind \& Alfaro, 2017; Kazadi et al., 2016; Prahalad \& Ramaswamy, 2000). Because it is valuable to know about customer motivations, resources and experiences, managers also need to know how to best manage co-creation, so as to realize its potential (Frow, Nenonen, Payne, \& Storbacka, 2015; Kazadi et al., 2016; Saebi \& Foss, 2015). In the news industry, content is created by experts (journalists) and the creation of knowledge is thus centralized and industrialized. The framing of the news is decided by news executives and journal- ists (i.e. reporters, photographers, and researchers) who rely on a variety of sources to assemble a news report, and this content is evaluated and amended by editors before publishing.

This way of producing newsworthy content is quite different from online crowdsourcing initiatives such as Linux, Lego MindBOARDS, Reddit, and Wikipedia. At Linux, programmers create open-source code in their spare time and at MindBOARDS, LEGO enthusiasts post source code and binaries for many different Lego Mindstorms tools (Pettersen, 2014). In 2015, the social news aggregation, web content rating, and discussion website Reddit had more than 73.15 million submissions, 725.85 million comments and 82.54 billion pageviews. As of February 2018, Reddit had 542 million monthly visitors (234 million unique users), ranking as the third most visited website in U.S. and sixth in the world ${ }^{1}$. The business model of Reddit is based on ads, and quality assurance of content is based on a decentralized upvoting mechanism done by the community's users. Another example of citizen's creation of content is Wikipedia, a crowdsourced encyclopaedia written collaboratively by the people who use it. Content is edited numerous times by other community participants, which aims to assure content quality. The Wikipedia business model is based on funding where the organisation only focuses on the handling the website, servers, and administration, and the main content is contributed by the volunteers for free. Wikipedia operates on a donation-based revenue model where the organisation gets most of its funds in the form of donations from millions of individuals and corporations around the world ${ }^{2}$. Thus, the creation of knowledge in Reddit and Wikipedia is distributed - and not centralized as traditional news actors - and different mechanisms from those of traditional media are at play to ensure content is correct, objective, and newsworthy.

One recurring argument for why traditional journalist practices are important to maintain and protect concerns content's objectivity and quality assurance. The ideal of journalists as objective is contested in current thinking of the impossibility of value-neutrality, hence this value has been renamed and reframed through concepts like "'fairness', 'professional distance', 'detachment' or 'impartiality', to (re-)legitimize what media practitioners do" (Deuze, 2005, p.448). The argument for detachment goes all the way back to the Lippmann vs. Dewey debate. In the Dewey tradition, feminist media scholars argue for subjectivity as a constitutive element of a professional identity of journalists (Van Zoonen, 1998). Deuze (2005, p.456) also acknowledges that new media technologies and cultural plurality make the idea of detachment and the core value of objectivity more complex, as "the discourse of professional distance clearly stands in 
stark contrast to the rhetoric of inclusivity". However, having several people's interpretations and thoughts on the same piece of content in online initiatives such as Reddit and Wikipedia, assist with adding depth to a story. Bayer, Ford, Tar, and Romanesco (2011), for example, found that a high number of editorial events in a Wikipedia page contribute positively to the page's quality. The characteristics of mass-collaboration projects such as Wikipedia, Reddit and many others, have illustrated how technologies in the 21st century enable large groups of people to crowdsource and cocreate, where individuals willingly contribute content without traditional organisational structures (Tapscott \& Williams, 2008). Just as journalists, these contributors are experts within their respective specialized fields in addition to being close to the social structure and context in which they create content. News organisations, however, are reluctant to benefit from this mass of users or producers in news production, despite that they, in recent years, have opened up for readers or users to engage in different ways with news content produced by journalists. We will now present the main strategies the press has used in order to engage readers.

STRATEGIES FOR USER INVOLVEMENT IN NEWS MEDIA Krumsvik (2013) identified four key strategies to create user involvement in the news industry: (1) the deliberation strategy (users have the opportunity to react to and interact with the produced and distributed content, but the selection of contributions from readers is influenced by journalistic practices and editorial attitudes); (2) the donation strategy (users are included in the production of content as professional journalists seek out user voices and encourage submissions, but the resulting content is still subjected to news industry practices and norms - typically referred to as "citizen journalism" or "participatory journalism"); (3) the distribution strategy (viral marketing is used to invite potential users to consume content); and (4) the data-gathering strategy (information about users and their interactions is collected and analysed in order to better serve those same users and potential advertisers).

Maintaining the editorial standards of news media has been a key concern of media executives. To ensure this, the legacy news media standard approach has been filtering and moderating user-generated content. While the readers have been encouraged to participate in the creation of content, they have not, to any noticeable degree, been invited to take part in the editorial decision-making process. This could be understood as a general scepticism towards the participants and reluctance to give up editorial power. Due to the high cost of moderation by editorial staff, some news outlets choose to outsource this control mechanism to third-party providers. Participants are, however, invited to help the moderator through reporting abusive content. News media often limit user-created content related to controversial news due to the cost of gatekeeping and content quality, i.e., the risk of ethical, legal, and brand reputation issues (Ihlebæk \& Krumsvik, 2015).

From Co-Producers to Distributors

Since the introduction of social media, many news media organisations have moved commentaries and debates to non-proprietary platforms (e.g. Facebook), and user participation has been redefined from fulfilling the social role of news media to promotional activities. A study conducted from 2012 to 2015 found that the role of users has been reframed from co-producers to distributors (Krumsvik, 2018). Distribution and data-gathering strategies are growing in importance, while the deliberation strategy declines. This indicates that promotion and business development have gained significance at the expense of the traditional focus on user participation to ensure the media's social role. At the same time, the approaches that are increasing in importance are those least likely to challenge the traditional understanding of journalists' professional role (Krumsvik, 2018).

While the main consequence of the deliberation strategy's diminishing importance is about the social 
role of the news media, the combined effect of this change in focus and the low priority of the donation strategy can also have consequences for user loyalty and therefore represent a marketing issue for news media.

Krumsvik's (2013) four strategies focus on different parts of the news actors' value chain, but they are alike in that the production and distribution of content ultimately remain under the control of the news actor. As said, the press is reluctant to embrace the many opportunities that lie in using technology to gain quality content free of charge, even at a time when news actors worldwide are struggling to find sustainable business models. Unfortunately, digital distribution has failed to solve the existential crisis of the newspaper industry (Thurman et al., 2018), and diminishing revenues are increasingly framed as a regulatory problem (Sjøvaag \& Krumsvik, 2017).

The donation strategy for creating user involvement (Krumsvik, 2013) includes citizen journalism, grassroots journalism, participatory journalism, and other terms describing the public's new role in the production of news. Despite being classified under the same category, these initiatives differ internally because they provide different degrees of control in the news production process. A close analysis of such initiatives reveals three ideal types of user involvement in the digital media landscape: (1) citizen reporting, (2) citizen journalism, and (3) citizen media. We label these as the three C's. The three C's are ideal types along an innovation continuum and stress certain elements common to most cases of the given phenomenon.

Citizen Reporting - the news player still in contro As the world's largest newsgathering network with a global web of partner TV channels, CNN made an initial attempt at citizen reporting ${ }^{3}$. At the initiative of CNN's TV operations, this network was extended by introducing the iReport in August 2006, a service enabling users carrying cameras or mobile phones to capture and share breaking news. This came about as a result of ad hoc initiatives inviting users to contribute images and stories, such as those from major disasters. CNN's iReport exemplifies how to utilize the economics of participatory news production: users provide breaking news video footage for free. The service further developed from its original intended function to include a "home video" style entertainment show on TV and a separate website for the direct submission of moderated, user-created content (Krumsvik 2013). The term "citizen reporting" clarifies the role of the user as a contributor in the input process, while journalism is the end result after professional vetting. Despite the fact that stories submitted to CNN's iReport are not edited, fact-checked, or screened before they are posted, all stories marked "CNN iReport" have been verified and cleared by CNN. The "iReporter" and CNN decide the newsworthiness of contributions together. Although one of the goals of CNN's iReport is to expand the current definition of news, CNN's producers still verify the information and decide which is added to CNN's coverage.

Citizen Journalism - citizens are invited in to the media actors' domain

An example of citizen journalism is OhmyNews ${ }^{4}$, a South Korean online news website founded in 2000 with the motto "Every Citizen is a Reporter". The platform accepts, edits, and publishes articles from its readers world-wide, and approximately $20 \%$ of the site's content was written by their 55-person staff.

The remaining was written by freelance contributors who were by large ordinary citizens. Thus, in OhmyNews, the users do the tasks normally performed by journalists. However, OhmyNews failed to expand globally, because verifying facts from around the world became too difficult for the website to handle. More recent initiatives of citizen journalism are for example Children's Radio Foundation (CRF) where young citizens are recruited as youth reporters across six countries in Africa, giving them the skills and tools to make their voices heard. They produce and present their own radio shows on local and national 
radio stations and via social media, about issues facing children and youth in communities. Radio is Africa's first choice due to low internet online access whereas nearly 90\% have access to a radio, making it a crucial source of information. In South Africa, CRF use platforms like WhatsApp to help station boost citizen journalism and listeners' feedback. Listeners are invited to contribute to the shows by using voice notes, group messaging, calling functions, and multimedia sharing. CRF is also mentoring radio stations to use WhatsApp to extend their reach and deepen their community engagement like creating WhatsApp forums where listeners can interact, or posting audio on WhatsApp to extend their broadcast. CRF is registered as a non-profit organisation in the US, the UK, and South Africa.

Citizen Media - the citizens and their community in control

In citizen media initiatives, the users initiate, produce, and control news content. AgoraVox is a French language website of news or journalistic blog powered by volunteers and non-professional writers, created by Carlo Revelli and Joël de Rosnay in March 2005, offering items by single or multiple writers ${ }^{5}$. Agora$V x^{6}$ has a distributed network of reporters and offers the opportunity to install a badge on the respective reporter's website or blog to make the reporter's col- laboration with AgoraVox visible. The articles/posts that a citizen reporter publishes on the AgoraVox platform are also published on his or her blog with a clear link to the AgoraVox version. Thus, in AgoraVox, a number of reporters produce the content, which is then distributed across different websites. Also, the editorial process differs from those of traditional news organisations. AgoraVox has an "editorial committee" with members that are independent reporters (editors) who have published at least 4 articles on the site. AgoraVox moderators are responsible for individually voting on each article according to its timeliness, relevance, and originality. Furthermore, beyond the verifications carried out by thousands of editors, the following process is based on feedback from readers. As soon as an article is published, any reader can freely intervene to comment on it, criticize it, complete it, enrich it, or denounce it. The author and the editor can interact with readers in order to complete and improve the article, and sometimes the editorial committee decides to delete an article after feedback from the editors. This process is considered as quality assurance. Content at AgoraVox is - similar to Wikipedia - free for readers to enjoy, and the business model is based on a donation strategy, including donations from the company Cybion, led by Revelli and de Rosnay, that is behind AgoraVox, in addition to revenue from advertising. AgoraVox is one of the most prominent European examples of a citizen journalism site (Bruno \& Klein Nielsen, 2012). However, even with low operating costs, the sustainability of the site will require more traffic to survive in a long-term (Bruno \& Klein Nielsen, 2012, p. 50).

Citizen media are examples of initiatives that concern Francis and Bessant's (2005) first two innovation P's: (1) product (changes in products/services); (2) process (changes in how products/services are created and distributed); as well as Storsul and Krumsvik's (2013) fifth dimension (5) social (changes that meet social needs and improve people's lives). These initiatives on the one hand cut production costs, and on the other, enable a diversity of perspectives and pieces of news content which in turn might assist participation in the civil society (Norsk telegrambyrå 2018 cited in Lamark 2018).

The three C's of the donation strategy (citizen reporting, citizen journalism, and citizen media) treat the seven steps of the news' production process differently. These seven steps are: who (1) assigns the article (i.e. the product), (2) does the research, (3) reports, (4) edits, (5) publishes, (6) updates, and (7) deletes the article or story. The differences are illustrated in Table 1.

As already tapped into, the three C's presented in Table 1 represent innovation in the news media as a continuum. In the literature, however, innovation is 
typically described in dichotomous terms; as either small improvements or fundamental changes. In the Schumpeterian tradition, the main dichotomy is that of incremental versus radical innovation. Incremental innovation refers to gradual improvements, where one innovation builds on another. Radical innovation, on the other hand, includes innovations with far-reaching consequences that may change the economy through creative destruction (Schumpeter, 1943). However, change is seldom either-or. On the contrary, they are closely interrelated, by building upon other elements, or putting different aspects together in new ways. For example, for Spotify to disrupt the music industry, it was of fundamental importance that tracks was detached from other songs (which was the practice on LPs and cassettes), a process that involved the digitization of music to digital formats (CDs). Hence, the electronic format of music was a key innovative stepping stone for players such as Spotify, where the stepping stone enabled the creation of a fundamentally new business model (the stream music model). Similarly, the three C's vary along an innovation continuum, in degrees of user involvement and roles in the traditional journalistic value chain. These aspects are related to and concern different parts in the news sites' business model. We will now discuss these in relation to the three C's before we conclude.

Table 1. User involvement and roles in the three C's from the perspective of the traditional journalistic value chain.

\begin{tabular}{llll}
\hline & Citizen reporting & Citizen journalism & Citizen media \\
\hline 1. Assignment & Editor* & User or editor & User \\
2. Research & Users or journalist & User & User \\
3. Reporting & Users or journalist & User & User \\
4. Editing & Editor & Editor & User \\
5. Publishing & Editor & Editor & User \\
6. Updating & Editor & Editor or users & User \\
& $\begin{array}{l}\text { Follows the practice of } \\
\text { traditional media: content is } \\
\text { not deleted due to the } \\
\text { organisation's control over } \\
\text { what gets published. }\end{array}$ & $\begin{array}{l}\text { Follows the practice of } \\
\text { traditional media: content is } \\
\text { not deleted due to the } \\
\text { organisation's control over } \\
\text { what gets published. }\end{array}$ & User \\
& $\begin{array}{l}\text { CNN's iReporting: users } \\
\text { contribute to the production } \\
\text { of journalism. }\end{array}$ & $\begin{array}{l}\text { OhmyNews or Children's } \\
\text { Radio Foundation: users do } \\
\text { the tasks normally } \\
\text { performed by journalists }\end{array}$ & $\begin{array}{l}\text { AgoraVox: users initiate, } \\
\text { produce, and control news } \\
\text { content }\end{array}$ \\
\hline
\end{tabular}

Note: *Reporting from breaking news events (e.g. accidents, terrorism, acts of war) will often be initiated by the user; however, this might be understood as an open assignment by the editor, as defined on the CNN iReport assignment website.

\section{DISCUSSION}

When we examine the three C's (citizen reporting, citizen journalism, and citizen media) through the lens of Osterwalder and Pigner's (2010) BMC framework, we can consider how the three C's are innovative in different ways for news actors, and how they repre- 
sent different business models towards a participatory business model (Table 2.).

As Table 2 shows, a citizen-reporting initiative represents few changes in both parts of the news media business model, thereby representing an incremental innovation. The back end of the business model (i.e. key activities) undergoes a minor change due to the opportunity for users to add their contributions.

The business model of citizen-journalism initiatives is quite similar to that of citizen reporting, except for greater change in the cost structure in the back end. This medium change denotes that users do the tasks normally performed by journalists. Hence news actors have less costs related to, for example, the salaries of journalists because content is produced free of charge by users. Moreover, this innovation represents an important step for radical innovation to take place.

Citizen media represent a radical innovation in Schumpeter's (1943) vocabulary, because all the dimensions in the business model's back end and front end are fundamentally different from those of traditional news players. From von Hippel's perspective on innovation, citizen media enable users to contribute with content they consider important to the community or society. Citizen media's value is produced by citizens and delivered to readers across a number
Table 2: User involvement in news production and degree of change in business model. The low, medium, and high values refer to the degree of innovation or change from traditional news actors' practices and business models.

\begin{tabular}{|c|c|c|c|c|}
\hline & & $\begin{array}{l}\text { Citizen } \\
\text { reporting }\end{array}$ & $\begin{array}{l}\text { Citizen } \\
\text { journalism }\end{array}$ & Citizen media \\
\hline \multirow{5}{*}{$\begin{array}{l}\text { Front end } \\
\text { business model }\end{array}$} & Customer segments & - & - & - \\
\hline & Channels & - & - & High \\
\hline & Customer relationships & Low & Low & High \\
\hline & Revenue structure & Low & Low & High \\
\hline & Value proposition & Low & Low & High \\
\hline \multirow{4}{*}{$\begin{array}{l}\text { Back end } \\
\text { business model }\end{array}$} & Key resources & Low & Low & High \\
\hline & Key activities & Medium & Medium & High \\
\hline & Key partners & - & - & High \\
\hline & Cost structure & Low & Medium & High \\
\hline Innovation type & & Incremental & $\begin{array}{l}\text { Medium pace of } \\
\text { change }\end{array}$ & Radical \\
\hline Example & & $\begin{array}{l}\text { CNN: users } \\
\text { contribute to the } \\
\text { production of } \\
\text { journalism }\end{array}$ & $\begin{array}{l}\text { OhmyNews or } \\
\text { Children's Radio } \\
\text { Foundation: } \\
\text { users do the tasks } \\
\text { normally } \\
\text { performed by } \\
\text { journalists }\end{array}$ & $\begin{array}{l}\text { AgoraVox: users } \\
\text { initiate, produce, } \\
\text { and control news } \\
\text { content }\end{array}$ \\
\hline
\end{tabular}


of citizen sites, different channels, and established customer bases and does not require a close relationship with clients since the producers are independent. The value-capture dimensions in the citizen media business model are conducted by citizens or users who produce content, so no key resources from the news media actor are needed in order to produce content. Editing is conducted by a committee of news producers, and no other key activities are needed in order to complement the business model. Finally, value is delivered directly to the market without any marketing costs or client segmentation. Content is produced by locals and distributed across a network of sites and platforms. Citizens media's participatory business model uses the potential of co-creation and a democratized Internet. By inviting readers to cocreate newsworthy content, segments of the customer relationships (back-end in the business model) are transformed into one of the news actors' key resources, activities and partners (front-end in the business model), yet with lower costs than internal resources traditionally require. However, adapting a participatory business model on all or parts of existing news services (e.g. local news), requires more than technological platforms alone, and several strategic shifts from news actors are needed; moving from controlling to orchestrating resources; from optimizing internal processes to facilitating external interactions; and from increasing customer value to maximizing the value of the ecosystem (Van Alstyne, Parker, \& Choudary, 2016). Furthermore, the economics of online journalism start-ups are as challenging for newcomers as for old-timers (Bruno \& Klein Nielsen, 2012), and getting a critical mass of contributors and traffic to the site will be important in order for growth and survival.

\section{CONCLUSIONS}

We have pointed out which parts of a news actor's business model could be innovated in order to turn the negative spiral. How the news media want to do this is not the scope of this article. By addressing the research question "Which elements, and to what degree, of news organisations' business model need innovation or change in order to benefit from the user's co-creation of content?", we revealed three ideal types or combinations of user involvement initiatives: (1) citizen reporting, (2) citizen journalism, and (3) citizen media. From a business model perspective, we revealed that citizen-reporting initiatives represent a low degree of innovation in the business model compared to news media's traditional business model, and citizen journalism represents a moderate degree of innovation. Citizen media, however, represents a high degree of innovation in both the back end and front end of the news media business model, representing a radical innovation. The citizen media business model is thus a fully participatory business model.

The analysis found that citizen media initiatives represent major opportunities in two senses: First, from a social innovation perspective (Ní Bhroin, 2015), citizen media involves the use of media and communication services for social purposes by meeting social needs for an enlightened society and improves people's lives by providing citizens the opportunity to be political participators (Krumsvik, 2018; Mulgan, Tucker, Ali, \& Sanders, 2007). From an epistemological perspective, having several people's interpretations and thoughts on the same case or content will add complexity and depth to the content in ways that would not be possible for one individual to supply in isolation. Thus, in terms of knowledge creation, citizen media initiatives would correspond with the findings of Bayer et al. (2011), who found that a high number of editorial events in Wikipedia contribute positively to quality. Also, having citizens who know different local subject areas very well enables the addition of complexity and meaning to a piece of content that covers several domains. A news journalist, who often has very little time to do so, cannot compete with this.

Second, from a business perspective, crowdsourced newsworthy content initiatives represent 
ways for news organisations to foster or grow quality content for free or at a very low cost.

In either case, a lack of control of the production processes need to be surrendered. This might be a key barrier for many news organisations because this represents profound changes to established industry practices and business models. This is one of the two well-known types of barriers for business model innovation in organisations (Chesbrough, 2010; Saebi \& Foss, 2015): One concerns the firm's inability to adjust existing resources to complex change, the other concerns the constraining effect of the current business model upon potential new ideas. Both types are observed in news organisations where professional journalists still produce the content and where the distribution of content remains, ultimately, under the control of the news actor, typically because traditional journalists fear the weakening of professional norms or the news media's credibility (Krumsvik, 2013). Standing in the way of business model innovation in the news industry may therefore be the very heart of the news industry - namely, the industry's established traditions, routines, norms, and control practices.

\section{Lene Pettersen}

Associate professor, University of Oslo

lenpe@ifi.uio.no

\section{Arne Krumsvik}

Professor, Kristiania University College

arne.krumsvik@kristiania.no

NOTES

1. https://en.wikipedia.org/wiki/Reddit

2. https://www.feedough.com/how-does-wikipediamake-money-wikipedia-business-model/

3. Please refer to

http://ireport.cnn.com/faq.jspa\#cnnireport

4. Please refer to http://english.ohmynews.com/

5. https://en.wikipedia.org/wiki/AgoraVox

6. Please refer to

http://www.agoravox.fr/qui-sommes-nous/faq-etconseils/article/devenir-redacteur-124

\section{REFERENCES}

Barland, J., \& Olsen, R. K. (2015). Innholdsmarkedsføring testet på lesere av nettaviser. Høgskolen i Gjøviks rapportserie. Gjøvik: Høgskolen i Gjøvik. http://hdl. handle.net/11250/2359010
Bayer, Ford, Tar, \& Romanesco. (2011). Quantifying quality collaboration patterns, systemic bias, POV pushing, the impact of news events, and editors' reputation. The Signpost. Retrieved from https://en.wikipedia.org/ wiki/Wikipedia:Wikipedia_Signpost/2011-11-28/Recent_research

Boczkowski, P. J. (2004). Digitizing the news: Innovation in online newspapers. Cambridge, MA: The MIT Press.

Bruno, N., \& Klein Nielsen, R. (2012). Survival is Success Journalistic Online Start-Ups in Western Europe. Reuters Institute for the Study of Journalism. RISJ CHALLENGES. University of Oxford. ISBN 978-1907384-08-0

Bruns, A. (2005). Gatewatching: Collaborative Online News Production. New York: Peter Lang.

Bruns, A. (2008). Blogs, Wikipedia, Second Life, and Beyond. From Production to Produsage. New York: Peter Lang.

Carpentier, N. (2011). Media and Participation. A Site of Ideological-Democratic Struggle. Bristol, UK/Chicago, IL: Intellect.

Chesbrough, H. (2010). Business model innovation: opportunities and barriers. Long Range Planning, 43(2), 354-363.

Chesbrough, H. W. (2003). Open innovation: The new imperative for creating and profiting from technology. Boston: Harvard Business Press 
Chesbrough, H. (2010). Business model innovation: opportunities and barriers. Long Range Planning, 43(2), 354-363.

Chesbrough, H. W. (2003). Open innovation: The new imperative for creating and profiting from technology. Boston: Harvard Business Press.

Deuze, M. (2005). What is journalism? Journalism, 6(4), 442-464. doi: 10.1177/1464884905056815.

Domingo, D. (2008). Interactivity in the daily routines of online newsrooms: dealing with an uncomfortable myth. Journal of Computer-Mediated Communication, 13(3), 680-704. doi: 10.1111/j.10836101.2008.00415.x.

Foss, N.J. \& Saebi, T. (2015). Business models and business model innovation: Bringing organisation into the field, in: N.J. Foss \& T. Saebi (Eds.), Business model innovation: The organisational dimension. Oxford: Oxford University Press.

Francis, D. \& Bessant, J. (2005). Targeting Innovation and Implications for Capability Development. Technovation, 25(3), 171-183.

Frow, P., Nenonen, S., Payne, A., \& Storbacka, K. (2015). Managing co-creation design: A strategic approach to innovation. British Journal of Management, 26(3), 463-483.
García-Avilés, J., A., Carvajal-Prieto,M., Arias-Robles, F., De Lara-González, A. (2018). Journalists' views on innovating in the newsroom: Proposing a model of the diffusion of innovations in media outlets. Journal of Media Innovation.

Gillmor, D. (2004). We the Media. Grassroots Journalism, By the People, For the People. Sebastopol: O'Reilly Media.

Günzel, F. \& Holm, A. B. (2013). One size does not fit allunderstanding the front-end and back-end of business model innovation. International Journal of Innovation Management, 17(01).

Haas, T. (2007). The Pursuit of Public Journalism. Theory, Practice, and Criticism. London: Routledge.

Ihlebæk, K. A. \& Krumsvik, A. H. (2015). Editorial power and public participation in online newspapers. Journalism - Theory, Practice \& Criticism,16(4), s 470487. doi: 10.1177/1464884913520200

Ind, N., Iglesias, O. \& Schultz, M. (2013). Building brands together. California Management Review, 55 (3): 5-26.

Iglesias, O., Ind, N., \& Alfaro, M. (2017). The organic view of the brand: A brand value co-creation model. In J.M.T . Balmer, S. M. Powell, J. Kernstock, \& T. O. Brexendorf (Eds.), Advances in corporate branding (pp. 148-174). Palgrave Macmillan, London.
Jönsson, A. M. \& Örnebring, H. (2011). User-generated content and the news: Empowerment of citizens or interactive illusion? Journalism Practice, 5(2), 127-144.

Kazadi, K., Lievens, A., \& Mahr, D. (2016). Stakeholder co-creation during the innovation process: Identifying capabilities for knowledge creation among multiple stakeholders. Journal of Business Research, 69(2), 525-540.

Krumsvik, A. H. (2018). Redefining User Involvement in Digital News Media. Journalism Practice, 12(1), 19-31. doi: 10.1080/17512786.2017.1279025

Krumsvik, A. H., Milan, S., Ní Bhroin, N. \& Storsul, T. (2018). Making (Sense of) Media Innovations. In Marc Deuze \& Mirjam Prenger (Eds.) Making Media. Production, Practices, and Professions. Amsterdam University Press.

Lamark, H. (2018). Journalistikk eller lokal journalistikk. Norsk medietidsskrift, 25(3), 1-7.

Levinthal, D. A. \& March, J. G., (1993). The myopia of learning. Strategic Management Journal,14(S2), 95112.

Matheson, D. (2004). Weblogs and the epistemology of the news: Some trends in online journalism. New Media \& Society, 6(4), 443-468.

Miles, R. E., Miles, G., \& Snow, C. C. (2006). Collaborative Entrepreneurship: A Business Model for Continuous Innovation. Organizational Dynamics, 35(1), 1-11. 
Moore, J. E., \& Hatcher, J. A. (2019). Disrupting traditional news routines through community engagement: analysis Analysis of the One River, Many Stories media collaboration project. Journalism Studies, 20(5), 749764.

Mulgan, G., Tucker, S., Ali, R., \& Sanders, B. (2007). Social innovation: What it is, why it matters and how it can be accelerated. Working paper, Oxford Said Business School, http://eureka.sbs.ox.ac.uk/761/1/ Social_Innovation.pdf.

Ní Bhroin, N. (2015). Social media-innovation: The case of indigenous tweets. The Journal of Media Innovations, 2(1), 89-106.

Nygren, G. (2008). Yrke på glid: Om journalistrollens deprofessionalisering (Occupation on the skids: the de-professionalization of journalism). Stockholm: Institutet för mediestudier.

O’Reilly III, C. A., \& Tushman, M. L. (2008). Ambidexterity as a dynamic capability: Resolving the innovator's dilemma. Research in organizational behavior, 28 , 185-206.

Osterwalder, A., \& Pigneur, Y. (2010). Business model generation: A handbook for visionaries, game changers, and challengers. John Wiley \& Sons.

Pettersen, L. (2014). From Mass Production to Mass Collaboration: Institutionalized Hindrances to Social Platforms in the Workplace. Nordic Journal of Science and Technology Studies, 2(2), 29-40.
Pettersen, L. (2017). Sorting things out. A typology of the digital collaborative economy. First Monday, 22(8). doi: http://dx.doi.org/10.5210/fm.v22i18.7805. http://firstmonday.org/ojs/index.php/fm/article/ view/7805/6513.

Prahalad, C. K., \& Ramaswamy, V. (2000). Co-opting customer competence. Harvard business review, 78(1), 79-90.

Sjøvaag, H. \& Krumsvik, A. H. (2017). In Search of Journalism Funding. Scenarios for future media policy in Norway. Journalism Practice. doi: 10.1080/17512786.2017.1370972

Revang, Ø. \& Olaisen, J. (2014). Evig ung - en casestudie av relasjoner mellom nyskaping og drift. Magma, 17(8), 53-62.

Rogers, E. M. (2010). Diffusion of innovations. New York, US.: Simon and Schuster.

Rosen, J. (1999). The Action of the Idea. In T. Glasser (Ed.), The Idea of Public Journalism (pp. 21-48). New York: The Guilford Press.

Rosen, J. (2000). The Essence of Public Journalism. In J. Strömback (Ed.), Public Journalism på Svenska, SDMI Skrift nr. 3 (pp.10-16). Sundsvall: Demokratiinstitutet.

Saebi, T. (2016). Fremtiden for forretningsmodellinnovasjon i Norge. Magma, 19(7), 33-41.
Saebi, T. \& Foss, N.J. (2015). Business models for open innovation: matching heterogenous open innovation strategies with business model dimensions. European Management Journal, 33(3), 201-213.

Schroeder, R. (2004). Online review. Journalism Studies, $5(4), 563-570$.

Schumpeter, J. (1943). Capitalism, Socialism and Democracy. London: Routledge.

Storsul, T., \& Krumsvik, A. H. (2013). What is Media Innovation? In T. Storsul \& A. Krumsvik (Eds.), Media Innovations: A Multidisciplinary Study of Change. (pp. 13-26). Göteborg, Sweden: Nordicom, University of Gothenburg.

Tapscott, D., \& Williams, A. D. (2008). Wikinomics: How mass collaboration changes everything. New York, USA: Portfolio, the Penguin Group.

Teece, D. J. (2018). Business models and dynamic capabilities. Long Range Planning, 51(1), 40-49.

Van Alstyne, M., W., Parker, G. G., \& Choudary, P. (2016). Pipelines, platforms, and the new rules of strategy. Harvard Business Review, 94(4), 54-62.

Van Zoonen, L. (1998). A Professional, Unreliable, Heroic Marionette (M/F): Structure, Agency and Subjectivity in Contemporary Journalisms. European Journal of Cultural Studies, 1(1): 123-43.

von Hippel, E. (2005). Democratizing Innovation. MIT Press Cambridge, MA. London, UK. 
Wardle, C., Dubberley, S., and Brown, PD. (2014) Amateur footage: A global study of user-generated content. Tow Center for Digital Journalism. New York: Columbia School of Journalism.

Zott, C., Amit, R., \& Massa, L. (2011). The business model: recent developments and future research. Journal of management, 37(4), 1019-1042.

Whittington, R. (2001). What is strategy-and does it matter?. Cengage Learning EMEA. 